\title{
"Honey" can Prevent Epidural Fibrosis Development After Laminectomy: An Experimental Study
}

\author{
"Bal"Laminektomi Sonrası Epidural Fibrozis Gelişimini Engelleyebilir: \\ Bir Deneysel Çalışma
}

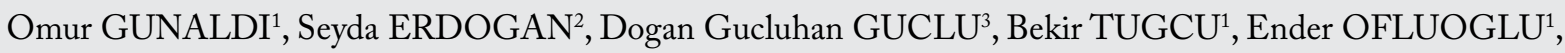
Serhat BAYDIN ${ }^{1}$, Erhan EMEL ${ }^{1}$

${ }^{1}$ Bakırkoy Research and Training Hospital for Neurology, Neurosurgery and Psychiatry, Neurosurgery Clinic, Istanbul, Turkey

${ }^{2}$ Cukurova University, School of Medicine, Department of Pathology, Adana, Turkey

${ }^{3}$ Bakırkoy Dr. Sadi Konuk Research and Training Hospital, Neurosurgery Clinic, Istanbul, Turkey

Corresponding Author: Omur GUNALDI / E-mail: omurgunaldi@gmail.com

\begin{abstract}
AIM: One of the most important causes of failed back surgery is the development of epidural fibrosis. Many methods and substances have been used to prevent the development of epidural fibrosis after laminectomy. In this study, effects of "manuka honey" on epidural fibrosis development after laminectomy was evaluated in rats.

MATERIAL and METHODS: Subjects were divided into two groups:In Group-1 ( $n=8)$;only laminectomy was carried out in the L1 level; in group-2 $(n=8)$, laminectomy was carried out in the L1 level and manuka honey was applied to the area. The related vertebral columns were removed en bloc 6 weeks later. Leveled sections with thicknesses of $6 \mathrm{~mm}$ were obtained from paraffin blocks.

RESULTS: In the grading made based on the fibroblast count and scar tissue degree, it was found that epidural fibrosis developed significantly less in the group-2 as compared to the group-1, and the difference was statistically significant.

CONCLUSION: It was shown in our study that manuka honey reduces the degree of epidural fibrosis in rats following laminectomy. We believe that manuka honey, which can be used safely in the clinic for surgical wounds, can be used routinely to prevent development of epidural fibrosis following laminectomy.
\end{abstract}

KEYWORDS: Peridural, Epidural, Fibrosis, Laminectomy, Honey, Rat

öz

AMAÇ: Başarısız bel cerrahisi sendromunun en önemli sebeplerinden biri epidural fibrozis (EF) gelişimidir. Laminektomi sonrası epidural fibrozis gelişimini engellemeye yönelik pek çok yöntem ve madde kullanıımıştır. Bu çalışmada, "manuka balı"nın laminektomi sonrası epidural fibrozis derecesine etkisi sıçanlarda değerlendirildi.

YÖNTEM ve GEREÇLER: Denekler iki gruba ayırıldı: Grup-1'de $(n=8)$ L1 seviyesine sadece laminektomi yapıldı, grup-2'de ( $n=8)$ L1 laminektomi yapılarak, laminektomi sahasına manuka balı uygulandı. Ilgili vertebral kolonlar 6 hafta sonra en-blok olarak çıkartıldı. Parafin bloklardan 6 mm kalınlığında seviyeli kesitler alındı.

BULGULAR: Skar dokusunun derecesine göre yapılan evrelemede, grup-2'de grup-1'e göre epidural fibrozisin daha düşük oranda geliştiği gösterildi. Aradaki farkın istatistiksel olarak anlamlı olduğu görüldü. Fibroblast sayısına göre yapılan evrelemede, grup-2'de grup-1'e göre daha düşük derecede epidural fibrozis geliştiği ve aradaki farkın istatistiksel olarak anlamlı olduğu tespit edildi.

SONUÇ: Çalışmamızda, manuka balı'nın sıçanlarda laminektomi sonrası EF derecesini azalttığı gösterilmiştir. Cerrahi yaralarda güvenli bir şekilde klinik olarak uygulanabilen manuka balı́nnın laminektomi sonrası epidural fibrozis gelişimini önlemek amacıyla rutin olarak kullanılabileceği kanaatindeyiz.

ANAHTAR SÖZCÜKLER: Peridural, Epidural, Fibrozis, Laminektomi, Bal, Sıçan

\section{INTRODUCTION}

The failed back surgery syndrome (FBSS) following lumbar disc herniation operations is reported in the literature at a rate of $5 \%$ to $40 \%(4,5,6,17)$. One of the most important causes of FBSS is the development of epidural fibrosis (EF). EF, which is seen in $24 \%$ of laminectomy patients, causes failed back surgery syndrome through the adhesions of the nerve roots, tension and compression (14). While many factors and mechanisms have been accused for the development of EF following laminectomy, many methods and substances have also been used to prevent its use. The majority of these have not been generally recognized in routine clinical practice, although they were successful in experimental studies. Another effect of honey, which is known for its many beneficial effects on human health both as a food and drug, is its modulating and enhancing effects on wound healing (15). 
Manuka honey $(\mathrm{MH})$, which is the drug form of honey, has not been used in neurosurgical areas, although it has been used in many studies involving its effects on wound healing and other clinical effects. In this study, the answer to the question of whether $\mathrm{MH}$, of which the positive results on wound healing have been reported in previous studies, can prevent the development of EF after laminectomy was sought.

\section{MATERIAL and METHODS}

This study was conducted under Cukurova University Animal Experimentation Local Ethics Committee approval (Decision \#: 16; July 2010) and was performed at Cukurova University School of Medicine, Experimental Animals Research Laboratory. $\mathrm{MH}$ produced by honeybees of Leptospermum scoparium species of New Zealand origin was used in the study. We used 16 Wistar Albino species rats that were 8. 10-12 weeks old and 200-250 $\mathrm{g}$ in weight.

\section{Surgical Procedure}

A single dose of $50 \mathrm{mg} / \mathrm{kg}$ ceftriaxone (Rocephine, Roche, Turkey) was administered through the intraperitoneal route for prophylaxis 30 minutes before the operation. Ketamine hydrochloride (Ketalar, Parke-Davis, Eczacıbaşı, Istanbul) $60 \mathrm{mg} / \mathrm{kg}$ was administered through the intraperitoneal route and Xylazine hydrochloride (Rompun) $10 \mathrm{mg} / \mathrm{kg}$ was administered for general anesthesia. After fixating the rat on the operation table, the operational area was brushed for 10 minutes with povidone iodine scrub (MEDICA brush; $\% 4$ chlorhexidine soap, MEDICA BV, Holland) and dyed with povidone iodine (POVIOD; $10 \%$ polyvinyl pyrrolidoneiodine complex, Saba, Turkey) solution for disinfection. The operation area was covered with sterile drapes. The L1 level was determined, and then a skin incision approximately $3 \mathrm{~cm}$ in length was made at the midline, on the spinous processes. The paraspinous muscles in the space were separated with blunt dissection. Laminectomy was performed. Subjects were divided into two groups: Group- $1(n=8)$ (Control group) only underwent laminectomy at the L1 level and group-2 $(n=8)$ (Treatment group) where laminectomy was performed at the L1 level and manuka honey was applied to the area. After keeping the subject alive for 6 weeks, euthanasia was performed with high dosages of thiopenthal sodium (75$100 \mathrm{mg} / \mathrm{kg}$ ) (Pentothal Sodium, Abbott, Italy). The related vertebral columns were removed en bloc 6 weeks later. Leveled sections with thicknesses of $6 \mathrm{~mm}$ were obtained from paraffin blocks. Rats where dural tears or nerve root injuries had occurred during the operation, or that developed postoperative neurological deficits or where infections were found during decapitation were excluded from the study. New rats were included in their places. The amount of fibrosis in the laminectomy area and the relationship with the dura mater were evaluated based on the histological criteria and classification found in the literature with comparisons made within the group and also with the control group and the results were compared statistically.

\section{Histopathological Evaluation}

After the vertebral column removed en bloc was fixed with buffered $10 \%$ formalin, it was decalcified for 2 days (10\% formic acid). Following the completion of decalcification, one specimen was collected from each area that laminectomy was performed. After the specimens were washed for 6 hours under running water, they were subjected to routine tissue follow-up procedure with the ototechnicon. Sections of $6 \mathrm{~mm}$ thickness were taken from the paraffin blocks according to level and were dyed with hematoxylin eosin. Each specimen was evaluated by a pathologist under the light microscope as regards cellular density and arachnoidal fibrosis. EF was evaluated as described by $\mathrm{He}$ and colleagues (11) (Table I). The extensity of the fibrosis was evaluated for each preparation. Cellular density in the scar tissue was evaluated as described by $\mathrm{He}$ and colleagues and by Hinton and colleagues $(11,12)$. Fibroblasts were counted by the pathologist under $40 \mathrm{x}$ magnification. This procedure was performed at three areas for each specimen, one in the mid portion, and two at the sides of the laminectomy. The mean fibroblast counts for these three areas were graded as shown in Table II.

Likewise, inflammatory cellular density was evaluated with 40x magnification. In addition, the presence of bone renewal, surrounding of the nerve root by scar tissue, and any adhesions between the dura and arachnoid were recorded. It was seen that less inflammation developed in the group that $\mathrm{MH}$ was applied as compared to the control group.

\section{Statistical Examination}

Data were evaluated using the SPSS 15.0 package program. The extensity of EF, cellular density and differences of arachnoid involvement were evaluated between the groups using the chi-square test. $\mathrm{P}<0.05$ was considered as statistically significant.

\section{RESULTS}

Grades of each rat in the control and treatment groups were determined based on the scar tissue level and fibroblast counts determined separately by the pathologist (Table III). For both grading systems, the EF grade for all the rats in group-2 was 2 or less and the EF grade for all the rats in group was 2 or more in group- 1 .

It was seen in the examination with light microscope that the thickness of EF, density of the inflammatory cells and arachnoidal adhesions in the subjects of group-1 were greater compared to those in the group-2 (Figures $1 \mathrm{~A}, \mathrm{~B} ; 2 \mathrm{~A}, \mathrm{~B}$ ).

Grading based on the level of the scar tissue, revealed no grade 0 or $1 \mathrm{EF}$ in group- 1 while $25 \%$ of the subjects were had grade 2 , and $75 \%$ had grade $3 \mathrm{EF}$. However, grade $3 \mathrm{EF}$ was seen in none of the subjects in group-2. EF was grade 2 in $37.5 \%$, grade 1 in $62.5 \%$, and there was grade 1 or 0 fibrosis in $62.5 \%$ (Figure 3, Table IV). Based on this grading system, it was found that less EF developed in group- 1 as compared to group-2 and the difference was statistically significant $(p<0.05)$. 
Table I: Grading Criteria for the Scar Tissue in the Histological Assessment (29)

\begin{tabular}{|c|l|}
\hline Grade & Width of the scar tissue \\
\hline 0 & No scar tissue in Dura mater \\
\hline 1 & Thin fibrous bands present between the scar tissue and dura mater \\
\hline 2 & Adhesions involving less than two-thirds of the laminectomy defect \\
\hline 3 & Widespread scarring. More than two-thirds of the laminectomy defect has been affected \\
\hline
\end{tabular}

Table II: Grading According to Fibroblast Numbers

\begin{tabular}{|c|c|}
\hline Grade & Mean fibroblast number (40x) \\
\hline 1 & $100>$ \\
\hline 2 & $100-150$ \\
\hline 3 & $150<$ \\
\hline
\end{tabular}

Table III: Level of Fibrosis in Rats in Control and Treatment Groups

\begin{tabular}{|c|c|c|c|c|}
\hline & \multicolumn{2}{|c|}{ Grade acc. to Table I } & \multicolumn{2}{c|}{ Grade acc. to Table II } \\
\hline No & Group 1 & Group 2 & Group 1 & Group 2 \\
\hline 1 & 3 & 2 & 3 & 1 \\
\hline 2 & 3 & 1 & 3 & 1 \\
\hline 3 & 3 & 1 & 3 & 1 \\
\hline 4 & 3 & 1 & 3 & 1 \\
\hline 5 & 3 & 0 & 3 & 1 \\
\hline 6 & 2 & 2 & 2 & 2 \\
\hline 7 & 2 & 2 & 2 & 2 \\
\hline 8 & 3 & 1 & 3 & 1 \\
\hline
\end{tabular}

In the grading based on the fibroblast count, grade 0 or $1 \mathrm{EF}$ was not seen in group- 1 , while $25 \%$ of the subjects had grade 2 , and $75 \%$ had grade $3 \mathrm{EF}$. However, grade 0 and grade $3 \mathrm{EF}$ was not observed in group-2. Grade $1 \mathrm{EF}$ was observed in $75 \%$ of the subjects, while grade $2 \mathrm{EF}$ was observed in $25 \%$ (Figure 4, Table V). Based on this grading system, it was found that EF with lower grade developed in group-1 as compared to group- 2 and the difference was statistically significant $(p<0.05)$.

\section{DISCUSSION}

One of the most important causes of failed back surgery is the development of epidural fibrosis following laminectomy $(3,9,18,19)$. EF consists of a mixture of cellular elements containing fibroblasts and inflammatory cells. The nerve will be distracted or compression will occur because of the contraction of the adhesions of the scar formation surrounding the nerve. Such adhesions can disturb the axoplasmic transport within the nerve fibers, arterial circulation and venous drainage $(3,9,18,19)$. Many studies have been performed and many substances have been used to prevent EF developing after spinal surgery including fatty grafts as a solid barrier, polyvinyl alcohol, hydrogel membrane, polytetrafluoroethylene membrane, polylactic acid membrane, vicryl mesh; sodium hyaluronate as a viscous
Table IV: Number of Rats at Each Stage Based on Grading According to Scar Tissue Level

\begin{tabular}{|l|l|l|l|l|}
\hline Group & Grade 0 & Grade 1 & Grade 2 & Grade 3 \\
\hline Group 1 & $0(0 \%)$ & $0(0 \%)$ & $2(25 \%)$ & $6(75 \%)$ \\
\hline Group 2 & $1(12.5 \%)$ & $4(50 \%)$ & $3(37.5 \%)$ & $0(0 \%)$ \\
\hline p & \multicolumn{4}{|c|}{0.011} \\
\hline
\end{tabular}

Table V: Number of Rats at Each Stage Based on Grading According to Fibroblast Numbers

\begin{tabular}{|l|c|l|l|l|}
\hline Group & Grade 0 & Grade 1 & Grade 2 & Grade 3 \\
\hline Group 1 & $0(0 \%)$ & $0(0 \%)$ & $2(25 \%)$ & $6(75 \%)$ \\
\hline Group 2 & $0(0 \%)$ & $6(75 \%)$ & $2(25 \%)$ & $0(0 \%)$ \\
\hline p & \multicolumn{4}{|c|}{0.002}
\end{tabular}

solution; gel recombinant tissue plasminogen activator as a fibrinolytic agent, urokinase; gelatin sponge as a hemostatic agent, microfibrillary collagen; and methylprednisolone, triamcinolone, prednisolone, ketaprofen, dexametasone as anti-inflammatory agent $(2,10,13,20)$. Although the use of these substances has been shown to be successful in animal models, it could not be demonstrated shown that they could provide a decrease in EF that was consistent with clinical improvement.

$\mathrm{MH}$ is a mixture containing various vitamins, minerals, amino acids and enzymes $(8,25)$. It has been used for wound healing, skin care and treatment of some diseases since the ancient ages (26). Studies in recent years have demonstrated antioxidant, antibacterial, anti-inflammatory, and antineoplastic effects and modulating effects on wound healing (25).

The anti-inflammatory effects of $\mathrm{MH}$ reduce edema and the amount of the exudates that form the scar tissue (16). Other studies have shown that $\mathrm{MH}$ modulates the inflammatory response, and provides controlled epithelial and fibroblast proliferation and angiogenesis (7). Phenolic components of $\mathrm{MH}$ provide low $\mathrm{pH}$, that is, a highly acidic environment. This acidic environment is mainly responsible for the antioxidant effect. An acidic environment, antioxidant effects, antiinflammatory effects, antibacterial properties and immunemodulator effects enable more rapid and adequate wound healing (7). Tonks et al. found in their study that the 5.8 $\mathrm{kDa}$ component of $\mathrm{MH}$ stimulates the TNF a production in macrophages through the toll-like receptor $(21,22,23)$. It was 
shown in some studies that the activity of the reactive oxygen species activated with thrombin that play a role in some pathological conditions are suppressed with $\mathrm{MH}$ and their amounts are reduced $(1,24)$.

Although $\mathrm{MH}$ has been used in wound healing in many studies as well as many other areas and its beneficial effects have been shown, it has almost never been used in studies involving the EF development after laminectomy and other procedures. The one and only study in this area is the study carried out by Faroki et al. (7). Honey produced by the honeybees in Dena Mountains within the Iranian borders was used in the study and it was shown that honey reduced EF development significantly.

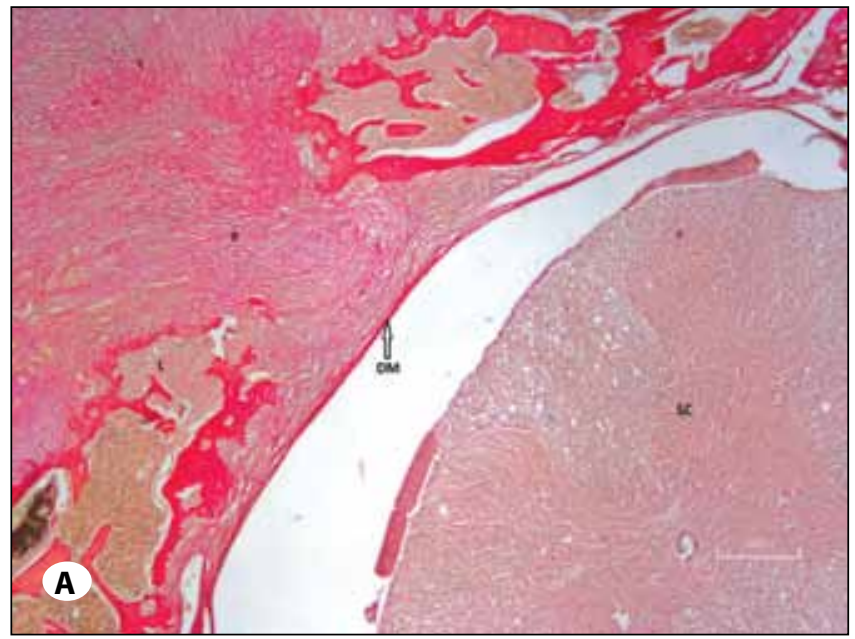

The FDA-approved drug form of $\mathrm{MH}$ was used in our study. Based on the histopathologic results of the study, it was found that both the fibroblast density and the thickness of the scar tissue were significantly lower in the $\mathrm{MH}$ group as compared to the control group. While grade 3 , which is the most intense grade of $\mathrm{EF}$, was seen in none of rats in the treatment group, the least observed grade in the control group was grade 2 . This result was found to be statistically significant. In addition, it was found in light microscope that the inflammatory cellular density in the control group was greater as compared to the treatment group.

These results are consistent with the results of the study carried out by Faroki et al., which is the only study on the use of

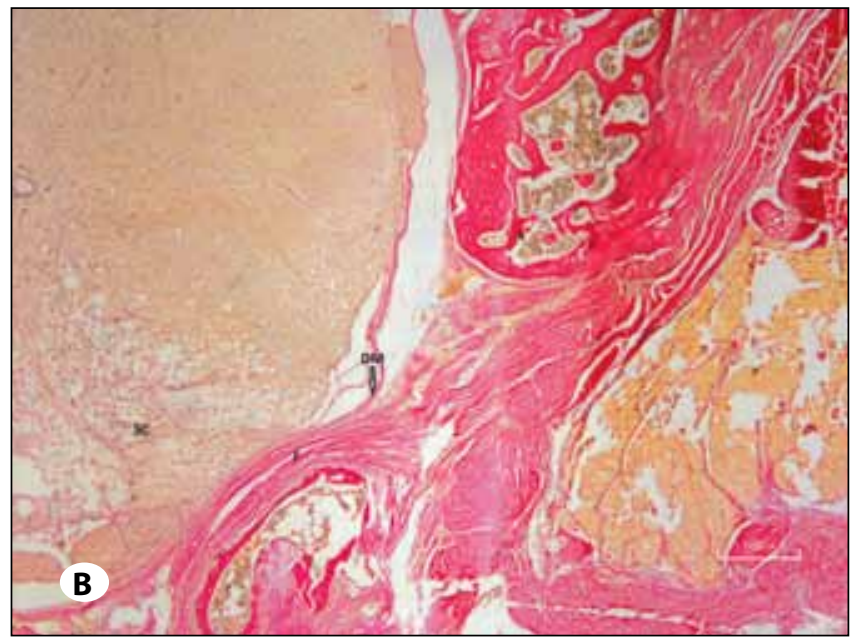

Figure 1: A) Photomicrograph showing Grade III fibrosis as observed in the control group. The epidural fibrosis was adhered to the underlying dura mater and spinal cord. $\mathbf{L}=$ lamina; $\mathbf{F}=$ fibrosis; $\mathbf{S C}=$ spinal cord; $\mathbf{D M}=$ dura mater. Scale bar=100 $\mu \mathrm{m}$. $\mathbf{B}) \mathbf{P h o t o m i c r o g r a p h}$ showing Grade III fibrosis as observed in the control group. The epidural fibrosis was adhered to the underlying dura mater and spinal cord. ( $\mathbf{L}=$ lamina; $\mathbf{F}=$ fibrosis; $\mathbf{S C}=$ spinal cord; $\mathbf{D M}=$ dura mater. Scale bar=100 $\mu \mathrm{m}$ ).
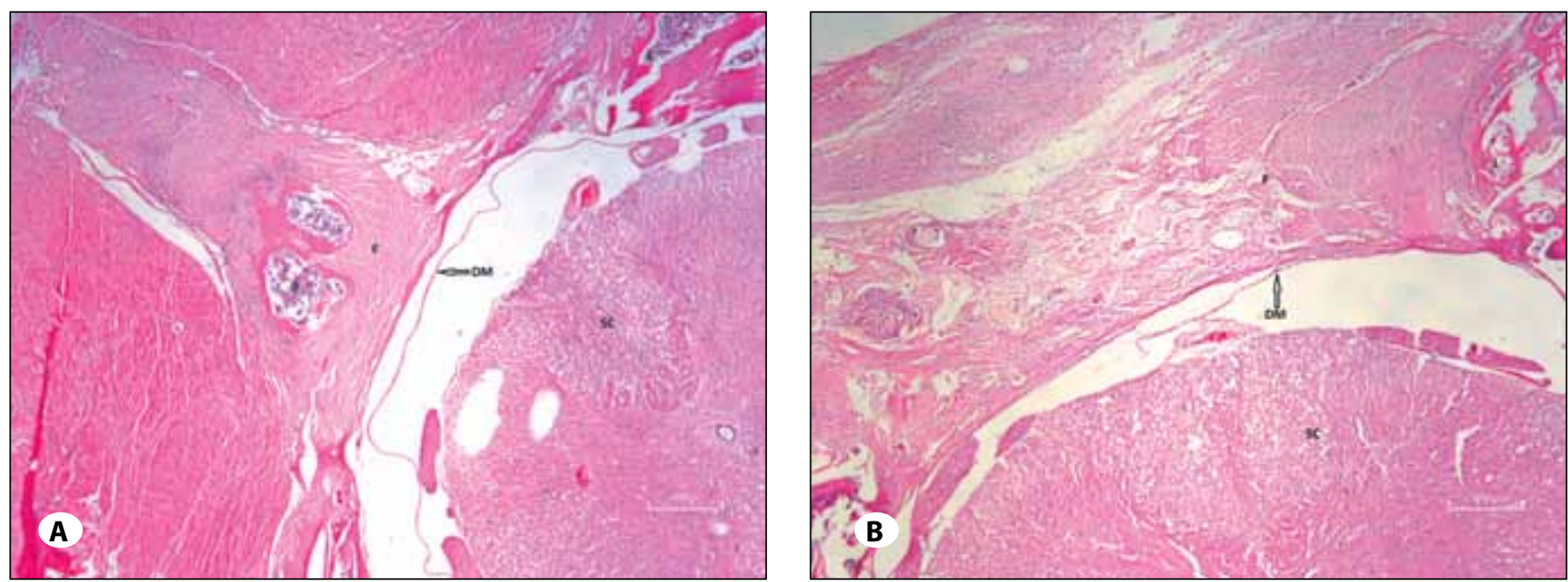

Figure 2: A) Photomicrograph showing Grade 1 fibrosis as observed in the manuka honey group. No direct contact between the underlying spinal cord and the epidural fibrosis tissue is evident. $\mathbf{F}=$ fibrosis; $\mathbf{S C}=$ spinal cord; $\mathbf{L}=$ lamina; $\mathbf{D M}=$ dura mater, $\mathbf{B}=$ bone. Scale bar $=100 \mu \mathrm{m}$. B) Photomicrograph showing Grade 1 fibrosis as observed in the manuka honey group. No direct contact between the underlying spinal cord and the epidural fibrosis tissue is evident. ( $\mathbf{F}=$ fibrosis; $\mathbf{S C}=$ spinal cord; $\mathbf{L}=$ lamina; $\mathbf{D M}=$ dura mater. $\mathbf{S c a l e}$ bar $=100 \mu \mathrm{m})$. 

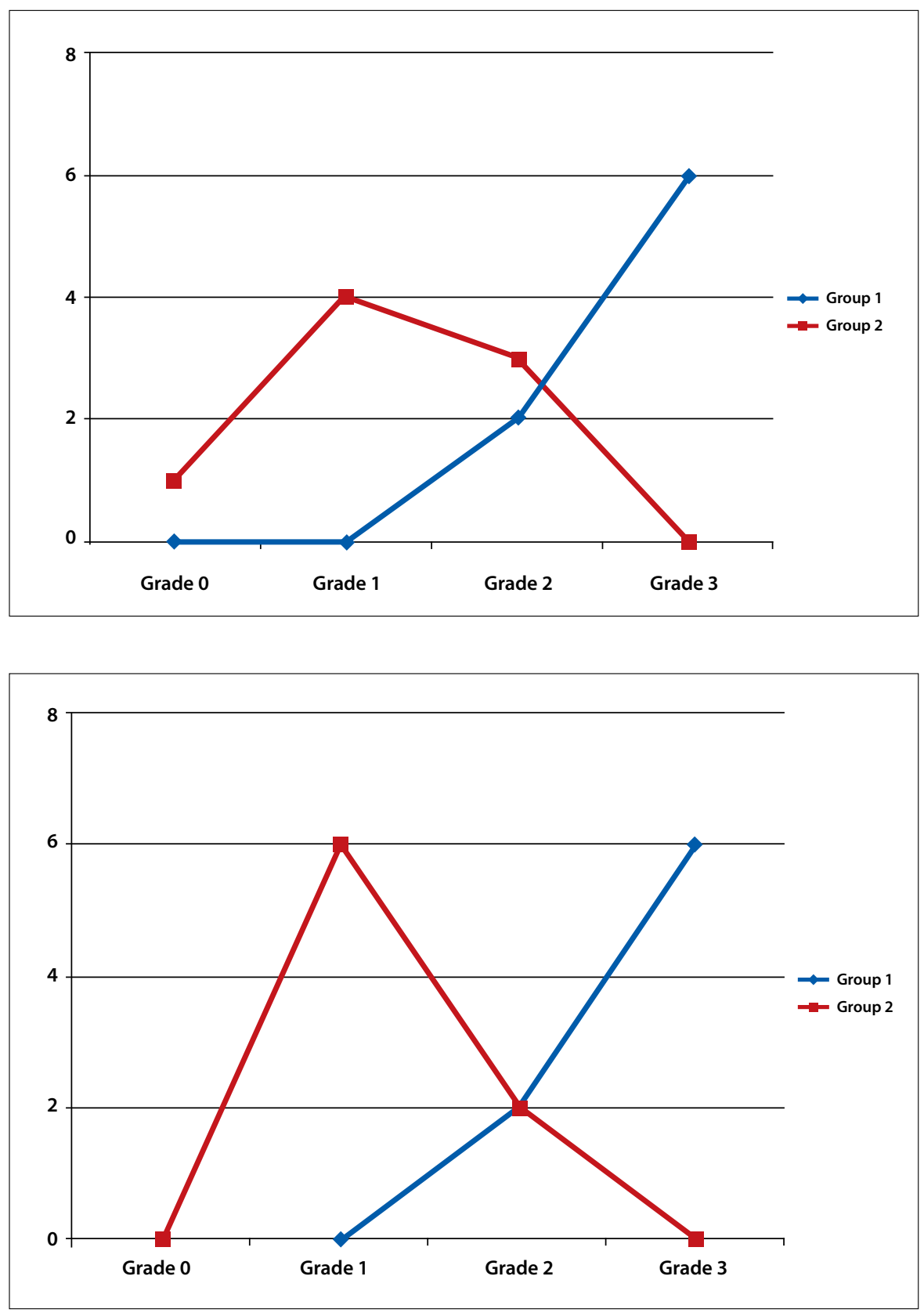

honey for development of EF after laminectomy. In addition, it was found to be consistent with studies involving the wound healing effect of honey. Infection, allergic reactions or other adverse effects were seen in none of the subjects.

In conclusion, based on our study, $\mathrm{MH}$ has reducing effects on EF after laminectomy in rats. It was confirmed that it is a natural product that can safely be used on live tissues. We conclude that $\mathrm{MH}$, which has been previously used safely in humans for wound healing, "can be safely used in EF studies in humans after laminectomy" according to the results of our study.
Figure 3: Histological results of epidural fibrosis grades in group 1 and 2.
Figure 4: Fibroblast count of group 1 and 2 .

\section{REFERENCES}

1. Ahmad A, Khan RA, Mesaik MA: Anti inflammatory effect of natural honey on bovine thrombin-induced oxidative burst in phagocytes. Phytotherapy Research 23(6):801-808, 2009

2. Alkalay RN, Kim DH, Urry DW, Xu J, Parker TM, Glazer PA: Prevention of postlaminectomy epidural fibrosis using bioelastic materials. Spine 28:1659-1665, 2003

3. Bartynski WS, Petropoulou KA: The MR imaging features and clinical correlates in low back pain-related syndromes. Magn Reson Imaging Clin N Am 15:137-154, 2007

4. Burton CV, Kirkaldy-Willis WH, Yong-Hing K, Heithoff KB: Causes of failure of surgery on the lumbar spine. Clin Orthop Relat Res 157: 191-199, 1981 
5. Choi HJ, Kim KB, Kwon YM: Effect of amniotic membrane to reduce postlaminectomy epidural adhesion on a rat model. $J$ Korean Neurosurg Soc 49:323-328, 2011

6. Fager CA, Freidberg SR: Analysis of failures and poor results of lumbar spine surgery. Spine (Phila Pa 1976) 5: 87-94, 1980

7. Farrokhi MR, Vasei M, Fareghbal S, Bakhtazad A: Effect of honey on peridural fibrosis formation after laminectomy in rats: A novel experimental study. Evid Based Complement Alternat Med 2011:504967, 2011

8. Fukuda $M$, Kobayashi $K$, Hirono $Y$, Miyagawa $M$, Ishida $T$, Ejiogu EC, Sawai M, Pinkerton KE, Takeuchi M: Jungle honey enhances immune function and antitumor activity. Evidencebased complementary and alternative medicine. Evid Based Complement Alternat Med 2011: 908743, 2011

9. Gill GG, Scheck M, Kelley ET, Rodrigo JJ: Pedicle fat grafts for the prevention of scar in low-back surgery: A preliminary report on the first 92 cases. Spine 10:662-667, 1985

10. Gorgulu A, Simsek O, Cobanoglu S, Imer M, Parsak T: The effect of epidural free fat graft on the outcome of lumbar disc surgery. Neurosurgical Review 27:181-184, 2004

11. HeY, Revel M, Loty B. Quantitative model of post-laminectomy scar formation. Effects of a nonsteroidal anti-inflammatory drug. Spine (Phila Pa 1976) 20:557-563, 1995

12. Hinton $\mathrm{JL}$, Warejcka DJ, Mei $Y$, McLendon RE, Laurencin $C$, Lucas PA, Robinson JS Jr: Inhibition of epidural scar formation after lumbar laminectomy in the rat. Spine (Phila Pa 1976) 20:564-570, 1995

13. Karaman H, Akay HO, Turhanoglu S: Broken racz catheter during application (case report). Ağrı 18:33-36, 2006

14. Kasimcan MO, Bakar B, Aktaş S, Alhan A, Yilmaz M: Effectiveness of the biophysical barriers on the peridural fibrosis of a postlaminectomy rat model: An experimental research. Injury 42:778-781, 2011

15. Lusby PE, Coombes A, Wilkinson JM: Honey: A potent agent for wound healing? J Wound Ostomy Continence Nurs. 29:295-300, 2002
16. Moore OA, Smith LA, Campbell F, Seers K, McQuay HJ, Moore RA: Systematic review of the use of honey as a wound dressing. BMC Complement Altern Med 1:2, 2001

17. North RB, Campbell JN, James CS, Conover-Walker MK, Wang $\mathrm{H}$, Piantadosi S, Rybock JD, Long DM: Failed back surgery syndrome: 5-year follow-up in 102 patients undergoing repeated operation. Neurosurgery 28: 685-691, 1991

18. Robertson JT: Role of peridural fibrosis in the failed back: $A$ review. Eur Spine J 5 Suppl 1:S2-56, 1996

19. Sizer PS, Phelps V, Dedrick G, Matthijs O: Differential diagnosis and management of spinal nerve root-related pain. Pain Pract 2:98-121, 2002

20. Temel SG, Ozturk C, Temiz A, Ersozlu S, Aydinli U: A new material for prevention of epidural fibrosis after laminectomy. J Spinal Disord Tech 19:270-275, 2006

21. Tonks AJ, Cooper RA, Jones KP, Blair S, Parton J, Tonks A: Honey stimulates inflammatory cytokine production from monocytes. Cytokine 21:242-247, 2003

22. Tonks A, Cooper RA, Price AJ, Molan PC, Jones KP: Stimulation of TNF-a release in monocytes by honey. Cytokine 14: 240-242, 2001

23. Tonks AJ, Dudley E, Porter NG: A 5.8-kDa component of manuka honey stimulates immune cells via TLR4. J Leukoc Biol 82:1147-1155, 2007

24. van den Berg $A J$, van den Worm $E$, van Ufford $H C$, Halkes $S B$, Hoekstra MJ, Beukelman CJ: An in vitro examination of the antioxidant and anti-inflammatory properties of buckwheat honey. J Wound Care 17:172-178, 2008

25. Viuda-Martos M, Ruiz-Navajas $Y$, Fernandez-Lopez J, PerezAlvarez JA: Functional properties of honey, propolis, and royal jelly. J Food Sci 73:R117-R124, 2008

26. Zumla A, Lulat A: Honey-a remedy rediscovered. J R Soc of Med 82:384-385, 1989 